\title{
SERTIFIKASI DAN PENGEMBANGAN KEMASAN TAPE
}

\author{
Ummu Harmain1 ${ }^{\# 1}$ dan Romauli Simanjuntak2\#1 \\ \#1Jurusan Agribisnis Fakultas Pertanian Universitas Simalungun \\ Jl. Sisingamangaraja Barat, Pematangsiantar \\ 1ummuharmain@gmail.com \\ 22romaulisimanjuntak08@gmail.com
}

\begin{abstract}
ABSTRAK
Usaha tape saat ini merupakan generasi kedua yang berjalan tanpa perkembangan yang berarti. Permasalahan utama yang dihadapi adalah belum berkembangnya pasar dan pengelolaan usaha yang masih sangat sederhana. Solusi yang ditawarkan adalah pengembangan pasar melalui sertifikasi produk dan pengembangan kemasan, pelatihan manajemen dan pembukuan usaha. Hasil yang diperoleh tersertifikasinya produk tape dengan memperoleh nomor pangan industri rumah tanggga ( $p$-irt), pengembangan pasar alternatif, pengelolaan dan pembukuan usaha yang lebih baik.
\end{abstract}

Keywords - Manajemen dan pembukuan usaha, pengembangan kemasan, sertifikasi produk dan tape.

\section{PENDAHULUAN}

Tape merupakan salah satu produk makanan yang cukup dikenal dan disukai oleh masyarakat Indonesia, mulai dari anak-anak sampai orang tua mengetahui makanan ini, begitu pula masyarakat kelas bawah maupun kelas atas tentu pernah mencicipinya. Selain dikonsumsi langsung, tape juga dapat dijadikan bahan campuran minuman seperti es doger dan es campur, teman makan emping, digoreng bahkan dibuat bolu dan kue.

Tape sebagai produk olahan dalam proses produksinya sudah seharusnya memenuhi cara produksi pangan olahan yang baik. Cara produksi pangan olahan yang baik adalah pedoman yang menjelaskan bagaimana produksi pangan olahan agar aman, bermutu dan layak konsumsi. [1] Terkait produk pangan olahan ada beberapa peraturan dan undang-undang yang mengatur tentang hal ini. Diantaranya yaitu PP. No. 28 / 2004 tentang Keamanan Mutu dan Gizi Pangan Pasal 43 ayat (2) yang menyatakan bahwa pangan olahan yang diproduksi oleh industri rumah tangga wajib memiliki sertifikat Produksi Pangan Industri Rumah Tangga [2] dan UU No. 36 / 2009 tentang kesehatan Pasal 111 ayat (1) bahwa makanan dan minuman yang digunakan masyarakat harus didasarkan pada standar dan persyaratan kesehatan. [3]

Undang-undang tersebut

mengamanahkan bahwa makanan dan minuman yang tidak memenuhi ketentuan standar, persyaratan kesehatan, dan/atau membahayakan kesehatan dilarang untuk diedarkan, ditarik dari peredaran, dicabut izin edar dan disita untuk dimusnahkan.

Demikian pentingnya produk pangan olahan dibuat dengan baik sehingga produk yang dihasilkan aman, bermutu dan layak konsumsi. Produk pangan yang aman, bermutu dan layak konsumsi merupakan hak azasi setiap manusia.

Hal lain yang penting bagi suatu produk adalah kemasan. Kemasan bagi suatu produk memiliki banyak fungsi, diantaranya sebagai pelindung, kemasan dapat menjadi penghias, pengenal, identitas, dan media informasi dari suatu produk. ${ }^{[4]}$ Kemasan yang menarik akan mendatangkan nilai lebih bagi produk yang dijual dan mengundang daya tarik bagi calon konsumen. Produk yang sebenarnya bagus menjadi kurang laku bisa jadi karena disebabkan oleh kurang baiknya kemasan. Dengan demikian kemasan produk perlu menjadi pertimbangan bagi pelaku usaha. 
Produk tape sebagaimana yang sering terlihat di pasaran biasanya dikemas menggunakan daun atau plastik. Kemasan seperti telah ada sejak dahulu tanpa ada perubahan yang cukup berarti. Dengan kemasan seperti ini sulit untuk meningkatkan nilai tambah produk tape. Demikian pula dengan tape yang dihasilkan mitra binaan. Tape yang dijual dikemas menggunakan daun pisang dan plastik transparan. Setiap kemasan tape berkisar $100 \mathrm{gr}$ dengan harga jual Rp 1.000.

Pemasaran tape dilakukan mulai pukul 09.00 14.00 dengan berjalan kaki menuju areal pemasaran masing-masing. Tape disusun rapi di dalam tampah dan dibawa dengan cara menjunjung di atas kepala. Zona pemasaran umumnya di sekitar kampung, kompleks perumahan atau ke pasar tradisional yang berada di sekitar wilayah Kota Pematangsiantar. Masing-masing penjual tape memiliki wilayah pemasaran sendiri sehingga tidak ada yang memasarkan tape di wilayah yang sudah dimasuki oleh penjual tape lainnya. Hal ini telah berlangsung bertahun-tahun dan belum terlihat adanya upaya yang mereka lakukan untuk meluaskan lingkup pasar.

Produksi tape dilakukan setiap hari. Bahan baku yang digunakan adalah singkong dan ragi. Bahan baku terbaik adalah singkong yang baru dipanen. Adapun jenis singkong yang banyak ditemui di Kota Pematangsiantar dan sekitarnya adalah singkong roti yang berwarna putih.

Proses produksi tape dimulai dengan mengupas kulit singkong. Setelah dikupas lalu dikikis sedikit permukaannya agar tape nantinya tidak berlendir. Setelah itu masukkan ke dalam air yang telah mendidih sampai cukup matang lalu angkat dan tiriskan. Apabila sudah cukup dingin tebarkan ragi secara merata dan tutup rapat agar proses peragian dapat berlangsung baik. Proses pembuatan tape secara grafis dapat dilihat pada gambar berikut:
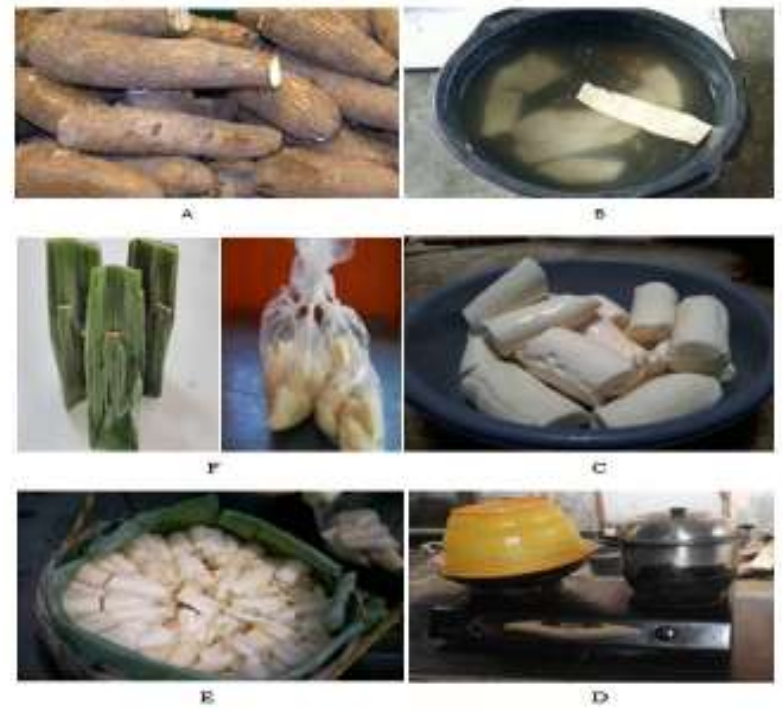

Gambar 1:

Searah jarum jam, a) singkong sebagai bahan baku b) dikupas dan dicuci c) tiriskan d) kukus e) taburi ragi lalu bungkus dengan daun f) tape siap dipasarkan/konsumsi

Proses peragian membutuhkan waktu selama 2-3 hari. Tape yang sudah jadi dibungkus dan siap dipasarkan. Rata-rata produksi harian tape mitra sebanyak $22.5 \mathrm{~kg}$, berasal dari $30 \mathrm{~kg}$ singkong. Tape dibungkus dengan daun pisang namun karena semakin langka keberadaannya maka lebih banyak dikemas dengan menggunakan plastik transparan.

Sebagaimana kebanyakan industri rumah tangga lainnya, usaha pengolahan tape meski sudah dijalankan dua generasi masih belum memiliki izin usaha, dikelola dengan manajemen yang masih sederhana. Belum ada pembagian kerja karena hampir semua kegiatan mulai dari penyediaan bahan baku, proses produksi sampai pemasaran masih dilakukan oleh pelaku usaha sendiri. Dengan demikian mereka tidak sempat berpikir lagi terhadap pengembangan usaha karena waktu tersita untuk melaksanakan berbagai kegiatan tersebut selain tugas rutin sebagai ibu rumah tangga. Banyaknya kegiatan yang harus mereka lakukan bahkan menyebabkan konflik peran antara pekerjaan dan rumah tangga. [5]

Hal yang sama juga terkait dengan pengelolaan keuangan, belum ada pembukuan terhadap transaksi usaha sehingga sulit untuk 
membedakan uang keluarga dengan uang hasil usaha.

Tape yang telah jadi dikemas dalam porsi kecil dibungkus daun pisang atau plastik transparan. Selain kurang menarik, bentuk seperti ini lebih sulit disusun dalam wadah saat didistribusikan. Tape disusun diatas tampah dengan cara menumpuk. Karena menggunakan kemasan seperti ini maka produk kurang menarik, daya simpan 2 - 3 hari dan produk semakin menyusut. Hal ini menjadi permasalahan dalam pengembangan pasar.

Kenyataannya, meskipun panganan ini sudah cukup lama dan merakyat namun jamak terlihat dipasarkan dengan cara-cara tradisional seperti menggunakan kemasan sederhana, tampilan yang kurang menarik, tidak setiap saat tersedia di pasaran sehingga konsumen tidak bisa sewaktu-waktu dapat memperolehnya. Begitu pula dengan tape yang diproduksi oleh Ibu Supinem dan Ibu Siti Awansih. Kedua mitra binaan ini merupakan generasi kedua dalam pembuatan tape yang telah ada sejak tahun 1977 di Kelurahan Bahkapul Kota Pematangsiantar.

Tujuan penulisan artikel ini adalah untuk, pertama, memfasilitasi perizinan usaha dan sertifikat P-IRT, kedua, pengembangan kemasan dengan kotak eksklusif, ketiga, pengembangan pemasaran dan keempat, memperbaiki pembukuan usaha.

\section{LUARAN}

Luaran yang dihasilkan dari kegiatan ini adalah:

1. UKM tape memiliki nomor Pangan Industri Rumah Tangga (P-IRT) dan surat keterangan usaha.

2. Kemasan tape menjadi lebih menarik dari sebelumnya.

3. Berkembangnya pasar.

4. Pembukuan usaha yang lebih baik.

\section{METODE PELAKSANAAN}

Metode pendekatan dan solusi yang ditawarkan dalam kegiatan ini adalah dengan penyuluhan, fasilitasi perizinan, pelatihan, pengembangan pasar serta pemberian peralatan.

Penyuluhan kesehatan dan keamanan pangan dilakukan bekerja sama dengan Dinas Kesehatan Kota Pematangsiantar. Dari kegiatan ini diperoleh sertifikat kesehatan dan keamanan pangan, dimana sertifikat ini merupakan syarat utama untuk pengurusan izin P-IRT.

Fasilitasi perizinan usaha dan sertifikat P-IRT dilakukan beberapa kegiatan yaitu 1) pengurusan izin usaha kecil dari kelurahan, 2) peninjaun lapangan oleh tim Dinas Kesehatan.

Kegiatan pelatihan dilakukan 1) pembuatan kemasan eksklusif, 2) pembuatan nama dagang atau merek dan informasi dalam kemasan tersebut dan 3) pembuatan pembukuan usaha.

Pengembangan pasar dilakukan dengan membuat warung penjualan di tempat strategis, 2) menawarkan ke pasar modern dan pusat oleholeh. Pemberian peralatan dilakukan terhadap peralatan yang sudah layak diganti.

\section{HASIL DAN LUARAN YANG DICAPAI}

Kegiatan yang dilakukan meliputi fasilitasi perizinan usaha dan sertifikat P-IRT, pelatihan pembuatan kemasan, pengembangan pasar, pembuatan pembukuan usaha, pendampingan dan monitoring kegiatan.

\section{A. Fasilitasi Perizinan Usaha dan Sertifikat P-IRT}

Untuk mendapatkan sertifikat P-IRT diperlukan beberapa persyaratan diantaranya 1) mengisi formulir permohonan SPP-IRT bermeterai yang ditujukan kepada Kepala Dinas Kesehatan. Dalam formulir ini tercantum nama pemohon, tempat tanggal lahir, pekerjaan, alamat, nomor KTP, NPWP, nomor telepon/hp, alamat usaha dan produk yang diproduksi. Dalam surat permohonan ini juga dilampirkan sertifikat penyuluhan keamanan pangan, rancangan etiket, KTP, pas photo, surat bersedia menanggung biaya pemeriksaaan laboratorium hasil produk bermeterai 6000 , data produk, data perusahaan industri rumah tangga dan surat keterangan usaha dari kelurahan. 
Dalam data produk tercantum nama produk, merek dagang, bahan baku, bahan tambahan makanan (pengawet, pemanis buatan, pewarna, pengembang dan pelembut), cara pembuatan, kemasan, masa simpan dan rancangan etiket.

Pada data perusahaan industri rumah tangga tercantum nama perusahaan, nama pemilik/penanggungjawab, nomor izin industri kecil dan alamat perusahaan. Dalam data ini terdapat keterangan mengenai lokasi perusahaan, apakah berada di pemukiman, industri, perkotaan atau daerah pertanian. Selanjutnya data karyawan, ruang pengolahan, fasilitas higiene sanitasi dan peralatan pengolahan.

Dari berbagai syarat yang diperlukan, sertifikat keamanan pangan merupakan syarat yang sulit untuk dipenuhi, kecuali telah mengikuti penyuluhan keamanan pangan yang diselenggarakan oleh Dinas Kesehatan. Berdasarkan hal yang dialami, penyuluhan keamanan pangan dilakukan berdasarkan permintaan.

Kegiatan penyuluhan keamanan pangan dilakukan selama dua hari yang diawali dengan pre-test. Tes ini dilakukan untuk mengetahui dan mengukur sejauhmana pemahaman pelaku usaha dalam membuat produknya sebelum dilakukan penyuluhan. Selanjutnya peserta mendapatkan penyuluhan keamanan pangan terkait dengan cara produksi pangan yang baik, diantaranya tentang keamanan pangan, cemaran dan kontaminasi pada produk olahan pangan serta teknologi produksi olahan pangan.

Setelah penyampaian seluruh materi dalam penyuluhan selesai, peserta kembali mengikuti ujian, dengan soalan yang sama dengan pre-test. Peserta penyuluhan dinyatakan lulus bila mendapatkan nilai 60. Diharapkan setelah kegiatan ini pengetahuan dan pemahaman pelaku usaha meningkat dalam memproduksi pangan, sesuai dengan kaidah produksi pangan yang baik dan aman.

Kegiatan penyuluhan keamanan pangan ini dilakukan di Dinas Kesehatan bersama dengan beberapa pelaku UKM produk pangan lainnya. Dari kegiatan ini Ibu Supinem mendapatkan Sertifikat Penyuluhan Keamanan Pangan No. 085/1273/17 dan Ibu Siti Awansih No. $086 / 1273 / 17$. Sertifikat ini merupakan salah satu syarat yang dibutuhkan untuk mendapatkan Sertifikat Pangan Industri Rumah Tangga (P-IRT). Suasana saat mengikuti penyuluhan keamanan pangan dapat dilihat pada gambar berikut:

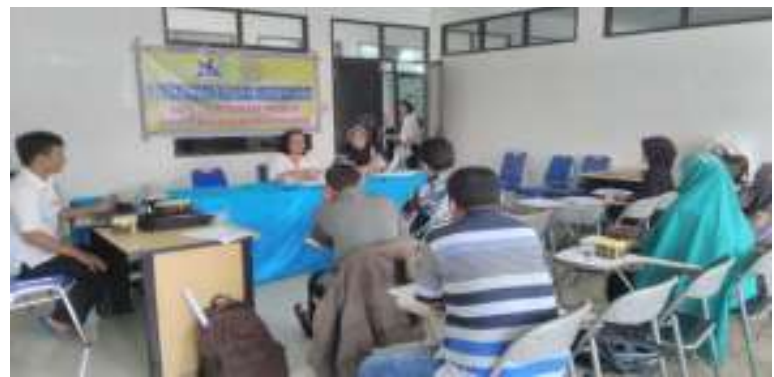

Gambar 2: Penyuluhan Keamanan Pangan

Langkah selanjutnya setelah memiliki sertifikat penyuluhan keamanan pangan adalah pengurusan surat keterangan usaha dari kelurahan. Untuk pengurusan surat ini dibutuhkan foto kopi KTP dan foto 2 lembar.

Beberapa hari setelah semua berkas dilengkapi, Tim Dinas Kesehatan meninjau lokasi UKM tape untuk melihat kondisi lapangan dan meninjau proses pembuatan produk. Elemen yang diperiksa diantaranya: lokasi dan lingkungan, bangunan dan fasilitas, peralatan produksi, sarana penyediaan air, fasilitas dan kegiatan higiene dan sanitasi, kesehatan dan higiene karyawan, pemeliharaan dan program higiene dan sanitasi, penyimpanan, pengendalian proses, pelabelan pangan, pengawasan oleh penanggungjawab, penarikan produk, pencatatan dan dokumentasi serta pelatihan karyawan. Dalam kunjungan tersebut diperoleh arahan dan masukan sehingga produk dihasilkan nantinya sesuai dengan standar keamanan pangan.

Dua hari setelah kunjungan ke lokasi, sertifikat produksi pangan industri rumah tangga usaha tape selesai. Mitra binaan Ibu Supinem mendapatkan sertifikat P-IRT dengan No. 2.151.273.02.0321.22 dan Ibu Siti Awansih dengan No. 2.15.1273.01.0321.22. Sertifikat PIRT ini berlaku untuk jangka waktu lima tahun. Sertifikat diterbitkan untuk satu jenis pangan produk. Sertifikat P-IRT kedua mitra binaan dapat dilihat pada gambar berikut: 


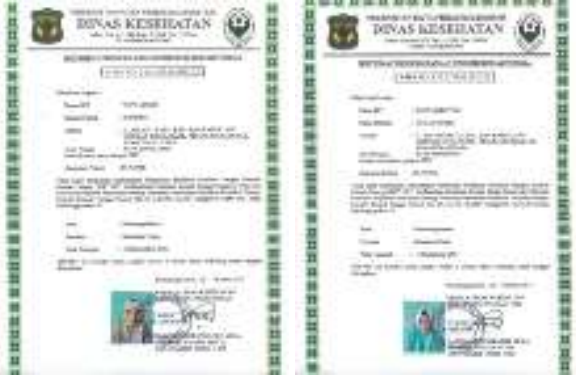

Gambar 3: Sertifikat P-IRT Mitra Binaan

Kepemilikan Sertifikat Produksi Pangan Industri Rumah Tangga (P-IRT) bagi industri rumah tangga yang menghasilkan produk pangan olahan selain merupakan suatu kewajiban juga menjadi keunggulan dari UKM tersebut. Kepemilikan sertifikat ini mempunyai beberapa manfaat, diantaranya. Pertama, pengakuan terhadap produk yang dihasilkan telah mengikuti cara produksi pangan yang baik. Kedua, garansi dari produsen kepada konsumen bahwa produk yang dihasilkan telah memenuhi cara produksi pangan yang baik sehingga dapat mengurangi kekhawatiran konsumen terhadap produk yang dikonsumsi. Ketiga, merupakan "lisensi" bagi UKM dapat memasukkan produknya pada pasar modern seperti swalayan dan supermarket karena biasanya pasar modern mensyaratkan hal itu bila ingin bekerjasama dengan mereka.

\section{B. Pelatihan Pembuatan Kemasan}

Satu hal yang tidak kalah pentingnya bagi suatu produk adalah kemasan. Kemasan adalah suatu wadah atau tempat yang digunakan untuk mengemas suatu produk yang dilengkapi dengan label atau keterangan-keterangan termasuk beberapa manfaat dari isi kemasan. [6]

Selain berfungsi sebagai wadah atau tempat, kemasan dapat menjadi pelindung, penghias, pengenal, identitas, media informasi, mempermudah penyimpanan dan transportasi bahkan sebagai alat persaingan dalam pemasaran suatu produk. Kemasan yang menarik akan mendatangkan nilai lebih bagi produk yang dijual dan mengundang daya tarik bagi calon konsumen. Dengan demikian kemasan produk perlu menjadi pertimbangan bagi pelaku usaha terutama produk makanan seperti tape.

Beberapa syarat kemasan yang baik diantaranya adalah tidak bersifat toksik, cocok dengan bahan yang dikemas, sanitasi dan syaratsyarat kesehatan terjamin, dapat mencegah pemalsuan, kemudahan dan keamanan dalam mengeluarkan isi, kemudahan pembuangan kemasan bekas, ukuran, bentuk dan berat, penampilan dan biaya rendah. [6]

Produk tape yang selama ini dijual mitra binaan menggunakan daun pisang atau plastik dengan berat sekitar 100 gr dengan harga jual Rp 1.000/bungkus. Terkesan produk yang dijual kurang layak bila dijual dengan harga yang lebih tinggi lagi. Untuk itu perlu dilakukan perubahan kemasan yang bersifat eksklusif dan menarik sehingga diharapkan dapat meningkatkan harga dan memberi nilai tambah yang lebih banyak.

Berdasarkan hasil diskusi dengan kedua mitra, kemasan baru akan menggunakan kertas karton yang dibuat dalam bentuk kotak. Sebenarnya ada masukan untuk membuat kemasan dari besek bambu namun karena ketiadaan kerajinan besek di wilayah sekitar maka pilihan ini ditinggalkan.

Selanjutnya adalah menentukan nama produk (merek). Langkah awal yang dilakukan adalah menginventarisir nama-nama yang diusulkan setelah itu dipilih satu nama. Dari berbagai nama yang telah diinventarisir, Ibu Supinem memilih nama Tape Manis dan Ibu Siti Awansih memilih nama Tape Maknyuss untuk nama produknya.

Langkah berikutnya adalah mendesain kotak. Kegiatan ini membutuhkan waktu yang lama karena dilakukan beberapa kali desain ulang sesuai dengan selera masing-masing. Setelah desain disepakati maka kotak siap untuk dicetak. Dalam konsep awal, kemasan primer tape adalah kertas dalam bentuk kotak, namun disebabkan jenis singkong yang digunakan sebagai bahan baku jenis singkong roti yang mengandung banyak air sehingga kemasan primer diganti menjadi plastik lalu dikemas dalam kotak. Dalam kemasan ini terdapat nomor sertifikat P-IRT, berat produk, informasi tanggal kadaluarsa, kode produksi, komposisi dan alamat usaha. Kemasan tape dapat dilihat pada gambar berikut: 


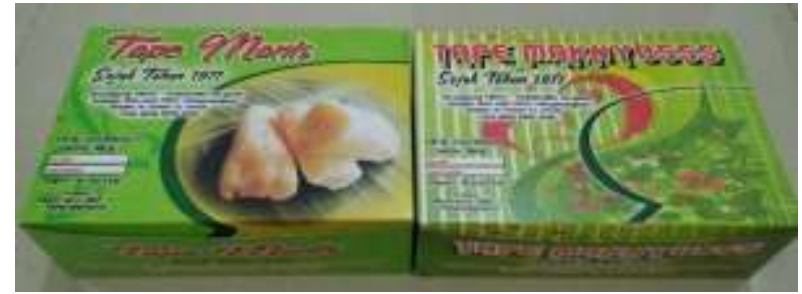

Gambar 4. Kemasan Tape Manis dan Tape Maknyuss

Selanjutnya menentukan berat produk yang dijual. Produk yang dijual selama ini berukuran $100 \mathrm{gr} /$ bungkus dengan harga jual $\mathrm{Rp}$ 1.000/bungkus. Berdasarkan pertimbangan maka disepakati berat produk yang akan dipasarkan 400 gr/kotak dengan harga jual Rp $10.000 /$ kotak.

\section{Pengembangan Pasar}

Dalam hal pemasaran UKM pada umumnya tidak mempunyai sumber daya untuk mencari, mengembangkan atau memperluas pasar-pasar mereka sendiri. Sebaliknya, mereka sangat tergantung pada mitra dagang (misalnya pedagang keliling, pengumpul atau trading house) untuk memasarkan produk-produk mereka, atau tergantung pada konsumen yang langsung datang ke tempat-tempat produksi. [7] Dengan demikian maka perlu dilakukan berbagai upaya untuk dapat mengembangkan pasar UKM. Berkembangnya pasar akan meningkatkan permintaan, menumbuhkan produksi, membutuhkan bahan baku dan akhirnya akan menggerakkan perekonomian masyarakat. Sejalan dengan itu, usaha tape mitra binaan juga tidak memiliki sumber daya yang mampu mengembangkan dan memperluas pasar.

Kegiatan penjualan tape dilakukan mulai pukul 09.00 - 14.00 dengan berjalan kaki menuju lokasi masing-masing. Tape disusun di atas tampah lalu dijunjung di atas kepala. Lokasi penjualan umumnya di sekitar kampung, kompleks perumahan atau pasar tradisional. Hal ini telah berlangsung selama bertahun-tahun dan sampai sekarang belum ada perubahan.

Secara empiris, dengan melakukan cara-cara ini produk yang mereka pasarkan selalu habis terjual, sehingga mereka tidak pernah merasa gagal dalam berusaha. Namun bila dilihat dari pertumbuhan usaha ternyata usaha hanya berjalan di tempat karena aset dan omzet relatif tetap. Hal ini menunjukkan bahwa usaha mampu bertahan cukup lama bukanlah disebabkan tingginya jiwa wirausaha namun lebih didorong oleh kebutuhan keluarga yang semakin besar.

Berdasarkan kondisi yang dimiliki mitra binaan maka kegiatan yang dilakukan untuk pengembangan pasar adalah 1) membuka pasar baru dengan memilih suatu tempat penjualan yang bersifat tetap di lokasi strategis dan memperpanjang waktu operasi mulai jam 09.00 - 16.00 WIB. Dari kegiatan ini diharapkan nantinya tertanam di benak konsumen bila ingin membeli tape langsung teringat lokasi tersebut. Selama ini meski tape sudah dikenal masyarakat namun susah memperolehnya sewaktu-waktu karena tidak adanya lokasi penjualan yang tetap, 2) mencoba memasuki pasar modern. Dalam hal ini telah menghubungi pihak Hypermart dan beberapa pasar modern lainnya, 3) beriklan di grup sosial media. Karena sempitnya waktu yang dimiliki pelaku usaha maka kegiatan ini melibatkan mahasiswa yang sedang mengikuti Mata Kuliah Kewirausahaan. Kegiatan ini masih dalam tahap awal, mampu menambah produksi tape UKM sebanyak $5 \mathrm{~kg} /$ hari diharapkan kedepannya produksi tape semakin meningkat.

\section{Pembuatan Pembukuan Usaha}

Setiap usaha apapun jenisnya memerlukan catatan keuangan (pembukuan) usaha. Banyak manfaat yang diperoleh dengan adanya catatan keuangan, diantaranya mengetahui besarnya keuntungan/kerugian usaha, posisi keuangan serta dapat dijadikan sebagai referensi untuk mengambil keputusan dalam suatu usaha.

Kenyataannya banyak UKM yang masih mengabaikan hal ini. Demikian pula dengan mitra binaan, selama ini belum pernah memiliki catatan keuangan (pembukuan) terkait usaha yang dilakukan. Sehingga uang hasil usaha bercampur dengan uang keluarga dan sulitnya mengetahui hasil usaha tape yang dilakukan.

Pada kegiatan ini hal yang dilakukan, pertama, penyuluhan tentang pentingnya catatan keuangan bagi suatu usaha, kedua, membuat pembukuan sederhana dan praktis. Materi yang disampaikan terkait dengan catatan keuangan adalah pentingnya pencatatan terhadap semua pengeluaran, pemasukan, aliran dana, catatan 
rugi laba serta mengumpulkan semua catatan/nota pengeluaran. Dengan demikian akan terlihat jelas aliran dana, omzet dan keuntungan yang mereka peroleh. Adanya catatan ini mempermudah pelaku UKM menekan biaya produksi, mengefisienkan biaya yang ingin dikeluarkan dan mengembangkan usaha.

\section{E. Pendampingan dan Monitoring Kegiatan}

Pendampingan dan monitoring awalnya dilaksanakan dua pekan sekali untuk semua kegiatan mulai dari pemakaian alat produksi, proses produksi, pemasaran dan manajemen usaha. Selanjutnya secara bertahap akan ditambah menjadi sebulan sekali sampai benarbenar bisa dilepas.

Pendampingan manajemen usaha ditempuh dengan cara memotivasi kedua mitra UKM untuk dapat mengurangi beban kerja yang selama ini mereka lakukan. Semua pekerjaan dilakukan sendiri mulai dari pembelian bahan baku sampai ke pamasaran. Untuk itu perlu memberdayakan anggota rumah tangga lainnya. Dengan demikian mereka dapat fokus mengerjakan tugasnya masing-masing sehingga produktifitas dapat meningkat.

Terkait dengan alat-alat produksi, diberikan bantuan beberapa alat produksi terutama yang sudah kurang layak digunakan. Penyerahan bantuan alat-alat produksi dapat dilihat pada gambar berikut:

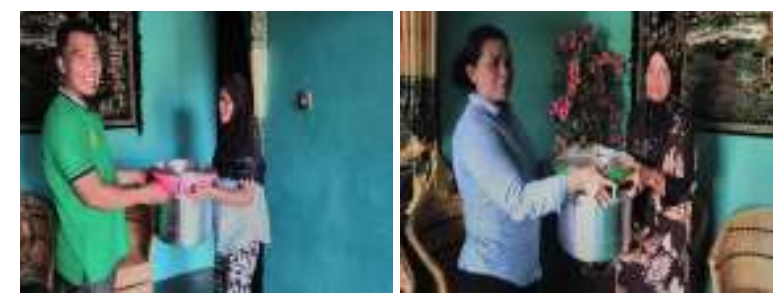

Gambar 5: Penyerahan Bantuan Alat Produksi

Dari seluruh rangkaian kegiatan yang dilakukan, kesulitan utama adalah menumbuhkan kebiasaan mencatat aliran dana. Untuk itu perlu waktu, kesabaran, kedisiplinan dan dukungan anggota rumah tangga lainnya untuk saling mengingatkan dalam mencatat aliran dana sehari-hari.

\section{KESIMPULAN DAN SARAN}

1. Produk tape mitra binaan telah tersertifikasi dengan diperolehnya izin P-IRT. Dalam proses pengurusan izin ini ada beberapa syarat yang harus dipenuhi, diantaranya memiliki surat keterangan usaha dari kelurahan, sertifikat penyuluhan keamanan pangan, rancangan etiket.

2. Kemasan tape yang awalnya hanya dengan daun pisang atau plastik transparan telah berubah menjadi kemasan kotak yang lebih menarik.

3. Metode pemasaran tape semakin bervariasi, yaitu dengan menempati suatu lokasi yang tetap dan menggunakan media sosial.

4. Mitra binaan telah memulai mengelola usaha dengan baik dan memiliki pembukuan usaha sederhana.

5. Pendampingan tetap perlu dilakukan meski seluruh rangkaian kegiatan yang diusulkan telah dilakukan sampai mitra binaan mampu mandiri. Untuk itu perlu komitmen yang kuat baik dari Tim Pengabdian maupun mitra binaan untuk dapat tetap menjalankan perannya dalam kegiatan ini.

\section{UCAPAN TERIMA KASIH}

Penulis mengucapkan terima kasih kepada Direktorat Riset dan Pengabdian Masyarakat Direktorat Jenderal Penguatan Riset dan Pengembangan Kementerian Riset, Teknologi dan Pendidikan Tinggi yang telah membiayai kegiatan ini dengan judul " IbM Tape, Sertifikasi Produk dan Pengembangan Kemasan" tahun pembiayaan 2017. Artikel ini merupakan bagian hasil dari hibah monotahun tersebut.

\section{DAFTAR PUSTAKA}

Peraturan Kepala Badan Pengawas Obat dan Makanan Republik Indonesia Nomor 11 Tahun 2014 Tentang Tata Cara Sertifikasi Cara Produksi Pangan Olahan Yang Baik.

Peraturan Pemerintah Republik Indonesia Nomor 28 Tahun 2004 tentang Keamanan Mutu dan Gizi Pangan.

Undang-undang Republik Indonesia Nomor 36 Tahun 2009 tentang Kesehatan. 
http://www.sulaemansaleh.my.id/2015/09/9. fungsi dasar kemasan yang anda harus ketahui.html. diakses tgl 19 maret 2016.

Harmain, Ummu et. al. Motivasi, Persepsi dan Konflik Peran Pekerjaan-Keluarga Entrepreneur Perempuan Daerah Istimewa Yogyakarta. Jurnal Agritech Vol. XVI No. 1 Juni 2014: 67 - 76.

Rahmawati, Fitri. 2013. Pengemasan dan Pelabelan. Materi Pelatihan Kewirausahaan bagi Kelompok UPPKS BPPM DIY. 9 - 11 September 2013.

Tambunan, Tulus. UMKM di Indonesia. Ghalia Indonesia. 2009: 75 